\title{
LA HERENCIA APOCALÍPTICA EN FRAY TORIBIO DE BENAVENTE, "MOTOLINÍA"*
}

\author{
THE APOCALYPTIC HERITAGE \\ IN FRAY TORIBIO DE BENAVENTE, "MOTOLINÍA"
}

\author{
Gabriela RoDRíGUEz SANDOVAL \\ Investigadora independiente \\ histmedieval@hotmail.com \\ ORCID: 0000-0002-3095-8661
}

\begin{abstract}
Resumen
En la historiografía existe un debate sobre la posible influencia del joaquinismo y del milenarismo en los franciscanos que llegaron a América en el siglo Xvi. Este artículo muestra otra vía para explicar sus inquietudes apocalípticas. En el Occidente cristiano persistió el anhelo de volver a encontrar el paraíso perdido antes del fin del mundo, y los esfuerzos se orientaron en proponer alternativas mesiánicas. Una de ellas fue el milenio del Apocalipsis de san Juan, pero al ser censurado surgieron diversas profecías que, de igual forma, referían un periodo de felicidad antes del fin, como la del emperador de los últimos días, la tercera época guiada por unos hombres espirituales de Joaquín de Fiore, etcétera. Desde el siglo XIII hasta el XVI, especialmente con Motolinía, el discurso franciscano utilizó estas profecías para explicar el devenir histórico y su propia historia.
\end{abstract}

Palabras clave: franciscanos; Motolinía; América; joaquinismo; milenarismo; escatología; felicidad.

\begin{abstract}
In historiography there is a debate about the possible influence of Joachinism and Millennialism on the Franciscans who arrived in America in the 16th century. This article tries to show another way to explain their apocalyptic concerns. In the Christian West, the desire to find the lost paradise before the end of the world persisted, and efforts were directed at proposing messianic alternatives. One of them was the millennium of the Revelation of St. John, but when it was censored several prophecies emerged that, in the same way, referred to a period of happiness before the end, like that of the emperor of the last days, the third period guided by spiritual men of Joachim de Fiore, etcetera. From the 13th century to the 16th century, especially with Motolinía, the Franciscan discourse used these prophecies to explain the historical future and its own history.
\end{abstract}

* El presente artículo está basado en mi tesis doctoral inédita intitulada "Una visión apocalíptica de la historia: la interpretación franciscana. Siglos XIII-XVI" (tesis de doctorado, Universidad Nacional Autónoma de México, 2018), realizada con beca del Conacyt. 
Keywords: Franciscans; Motolinía; America; Joachinism; Millennialism; eschatology; happiness.

Información del artículo

Recibido: 6 de enero de 2020.

Aceptado: 21 de abril de 2020.

DOI: http://dx.doi.org/10.22201/iih.24486922e.2020.63.72637

El Apocalipsis de san Juan, redactado hacia el siglo i d. C., fue un libro influyente y polémico por la interpretación material que de él se hizo, pues no nada más se creía que contenía los últimos eventos históricos que Dios le había revelado a Juan, sino que también refería un periodo de felicidad terrenal de mil años antes del fin del mundo: "Dichoso y santo el que participa en la primera resurrección; la segunda muerte no tiene poder sobre éstos, sino que serán sacerdotes de Dios y de Cristo y reinarán con él mil años". ${ }^{1}$ Si bien el discurso apocalíptico generaba miedo por las terribles tribulaciones anunciadas, también ofrecía esperanza al proponer una recompensa una vez pasado el sufrimiento.

El milenarismo tuvo un arraigo importante durante los primeros siglos cristianos; sin embargo, este discurso ya no iba acorde con la nueva realidad del cristianismo al convertirse en la religión oficial del imperio romano en el siglo IV d. C., y aunque el Apocalipsis de san Juan logró entrar en el canon cristiano, san Agustín le asestó un golpe fuerte, a pesar de que en un principio creyera en él, ${ }^{2}$ ya que debía interpretarse como el tiempo de la Iglesia, desde el nacimiento de Cristo hasta su segunda venida, ${ }^{3}$ había que sustituir la exégesis material por una espiritual. El discurso agustiniano siguió siendo apocalíptico puesto que seguía esperando el fin del mundo, pero en un futuro indeterminado. En este sentido, el relato del Génesis sirvió como referencia; así, si Dios había creado el mundo en seis días y en el séptimo había descansado, lo mismo pasaría en la historia, y san Agustín propuso que: "La primera edad, casi al tenor del primer día, venga a ser, desde Adán hasta el Diluvio, la segunda desde éste hasta Abraham [...].

${ }^{1}$ Ap 20 6, Biblia de Jerusalén, “Sepan cuantos...”, n. 500 (México: Porrúa, 1998).

${ }^{2}$ San Agustín, La Ciudad de Dios, "Sepan cuantos...”, n. 59 (México: Porrúa, 2008), libro xx, cap. 7, 600 .

${ }^{3}$ San Agustín, La Ciudad de Dios, 600, y cap. 8, 602. 
Desde Abraham hasta David, otra desde éste hasta la cautividad de Babilonia [...] desde aquí hasta el nacimiento de Cristo en carne". ${ }^{4}$

Luego el tiempo de la Iglesia hasta la segunda venida, y el Sabbat sería en el más allá, sin ningún tiempo intrahistórico como el milenio. El interés por los mil años siguió existiendo aunque fuera de manera soterrada, y también a raíz del anatema se exploraron nuevos caminos para que ese periodo de felicidad no desapareciera.

A raíz de la expulsión de Adán y Eva del paraíso, relatada por el Génesis, ese anhelo de felicidad recorrió un largo camino; de ahí la relevancia del mesianismo en el judeocristianismo ya que, como pueblos elegidos, en ellos se cumpliría la promesa del reino terrenal, como un restablecimiento del paraíso perdido. Y fue el Apocalipsis de san Juan el que estableció que ese reino debía durar mil años, por lo que en la cultura occidental quedó ese anhelo de volver a encontrar en la historia la felicidad primigenia, y esa "nostalgia" ha permitido que ese deseo se adapte. Más allá de que todavía hasta el siglo XVI se siguiera creyendo, igualmente, en la existencia física del paraíso, pero inaccesible al ser humano, y ubicado en algún lugar de oriente. ${ }^{5}$ Además del milenarismo, a lo largo de la historia cristiana surgieron varias propuestas para vivir la felicidad terrenal; por ejemplo, la profecía de un emperador de los últimos días de la Tiburtina, redactada en el siglo IV, la tercera época del Espíritu Santo guiada por unos hombres espirituales anunciada por el abad calabrés Joaquín de Fiore, la profecía de un papa angelical ( siglos XIII-XIV), ${ }^{6}$ así como la importancia que siguió teniendo el sueño de la estatua que Daniel le interpretó a Nabucodonosor, ${ }^{7}$ en donde se refiere la sucesión de los imperios históricos, y uno de ellos, el quinto, sería un reino escatológico que se establecería en la tierra. Se esperaba una época asimilada al paraíso, vivida en la historia y no en el más allá. Estos temas interactuaron con la apocalíptica tradicional, y al paso de los siglos se incorporarían al discurso apocalíptico.

En cuanto a Joaquín de Fiore (1135-1202) hay que indicar que fue un reputado profeta y exégeta que creyó ser el portador del conocimiento histórico, tanto pasado como futuro, pues a decir de él las Escrituras contenían toda la historia humana, y se podía acceder a este conocimiento por

${ }^{4}$ San Agustín, La Ciudad de Dios, libro xxiI, cap. xxx, 719-720.

${ }^{5}$ Véase Jean Delumeau, La historia del paraíso. El jardín de las delicias (México: Taurus, 2003).

${ }^{6}$ Véase el estudio de Martha H. Fleming, The Late Medieval Pope Prophecies. The Genus Nequam Group (Tempe: Arizona Center for Medieval and Renaissance Studies, 1999).

${ }^{7}$ Dn 2 29-45. Esta profecía va aparejada con la de las cuatro bestias: Dn 7. 
medio del método concordístico, de la inteligencia espiritual que había recibido en un viaje a tierra santa, ${ }^{8}$ y de la trinidad. Y el Apocalipsis de san Juan le servía para conocer la historia hasta su tiempo. Joaquín propuso una nueva teología de la historia, y dedujo tres etapas: la primera, la del Padre, pertenecía al Antiguo Testamento y prefiguraba la segunda, la del Hijo, a la que correspondía el Nuevo Testamento, y esta prefiguraba una tercera época, la del Espíritu Santo, que sería guiada por unos hombres espirituales del monacato y no por la Iglesia, y según los cálculos empezaría en el año de 1260. Joaquín rompía de alguna manera con la tradición agustiniana, que esperaba que la última etapa fuera trascendente. La exégesis del calabrés planteó problemas dogmáticos, de carácter trinitario y cristológico, pues Cristo y la Iglesia serían reemplazados por el Espíritu Santo y por unos hombres espirituales; sin embargo, antes de morir redactó una Carta-testamento adhiriéndose a la doctrina oficial de la Iglesia. Su exégesis trinitaria fue condenada por el Cuarto Concilio de Letrán (1215), ${ }^{9}$ pero la Iglesia nunca lo sancionó como hereje.

El cristianismo explotó estos temas con fines religiosos y políticos, y los franciscanos, asimismo, hicieron uso del discurso apocalíptico, y no sólo porque fueran cristianos, sino porque desde fechas tempranas se reconocieron como esos hombres espirituales profetizados por Joaquín de Fiore para guiar esa tercera época antes del fin del mundo; habían sido elegidos para ese propósito escatológico, y en esta lógica generaron nuevas interpretaciones, y su historia interna, como el contexto político-religioso de cada época franciscana, apoyó su interpretación apocalíptica de la historia.

Las expectativas apocalípticas se reactivaron con la aparición de América, y los llamados "doce" franciscanos que llegaron en 1524 tenían preocupaciones de esta índole. La polémica se ha centrado principalmente en si hubo o no influencia del milenarismo y del joaquinismo en los llamados “doce" y en Gerónimo de Mendieta. La opinión se encuentra dividida, unos apoyan la existencia de un milenarismo ligado al joaquinismo, donde los franciscanos pretendían fundar el reino milenario del Apocalipsis de san Juan. El ejemplo más representativo de esta postura es El reino milenario de los franciscanos de John L. Phelan, cuyo objetivo central fue Gerónimo de Mendieta. Más allá de que el autor caracterice a este franciscano como un

${ }^{8}$ Delno C. West y Sandra Zimdars-Swartz, Joaquín de Fiore. Una visión espiritual de la historia, Colección Cuadernos de la Gaceta, n. 22 (México: Fondo de Cultura Económica, 1986), 16.

${ }^{9}$ José Ignacio Saranyana, Joaquín de Fiore y Tomás de Aquino. Historia doctrinal de una polémica (Pamplona: Ediciones de la Universidad de Navarra, 1979), cap. 1. 
“apocalíptico elitista”, al que en ocasiones lo asaltaba la melancolía o la "tristeza apocalíptica”, quisiera resaltar otros aspectos de su trabajo. Por un lado, Phelan equipara la tercera época de Joaquín de Fiore con el milenio del Apocalipsis, y esto es un error, puesto que para el abad no es así, él esperaba su tercera época y no el milenio, por lo que, en el sentido estricto de la palabra De Fiore no es un milenarista. Sin embargo, la tesis que más controversia ha causado del trabajo de Phelan es la del reino milenario, pues, según este autor, Mendieta "Miraba hacia el futuro, pensando que los frailes y los indios podían crear el reino milenario del Apocalipsis", ${ }^{10}$ es decir, la esperanza en un reino que había sido anatematizado por la Iglesia desde el siglo Iv. Georges Baudot cree lo mismo, pero no de Mendieta sino de Motolinía: “[...] la esperanza de una próxima llegada del Reino, iba a dar a estos trabajos su verdadero sentido, al procurar los conocimientos indispensables para la fundación de una sociedad mexicana renovada, autónoma y preparada para el Milenio". ${ }^{11}$

En cambio, otros investigadores defienden un apocalipsismo ortodoxo de corte agustiniano, que había sido reavivado por la aparición de América, lo que les prevenía de que el fin del mundo estaba cerca. Niegan la influencia de un milenarismo ligado al joaquinismo y sustentan su crítica en que el reino de mil años había sido censurado e interpretado desde san Agustín como el tiempo de la Iglesia y del joaquinismo, porque había sido condenado en el siglo XIII y en el XIV a causa de proposiciones radicales, y aceptar estas influencias en los "doce" y en Mendieta pondría en duda su ortodoxia. A pesar de ello, para Lino Gómez Canedo el único que a su parecer mereciera calificarse de milenarista sería fray Martín de Valencia. ${ }^{12}$ Por su parte, Elsa Cecilia Frost, quien en algún momento apoyara las tesis de Phelan reconociendo la influencia de los espirituales a través de la profecía de la estatua de Daniel en los franciscanos del siglo XvI, ${ }^{13}$ indica que a pesar de que Phelan había leído el texto de Norman Cohn sobre el milenarismo

${ }^{10}$ John L. Phelan, El reino milenario de los franciscanos en el Nuevo Mundo (México: Universidad Nacional Autónoma de México, Instituto de Investigaciones Históricas, 1972), 109.

${ }^{11}$ Georges Baudot, Utopía e historia en México: los primeros cronistas de la civilización mexicana (1520-1569) (Madrid: Espasa-Calpe, 1983), 17.

${ }^{12}$ Lino Gómez Canedo, Evangelización, cultura y promoción social. Ensayos y estudios críticos sobre la contribución franciscana a los orígenes cristianos de México (siglos XVI-XVIII), Biblioteca Porrúa, n. 109 (México: Porrúa, 1993), 154.

${ }^{13}$ Elsa Cecilia Frost, "El milenarismo franciscano y el profeta Daniel”, Historia Mexicana, v. 26, n. 1 (1976): 3-28. 
medieval ${ }^{14}$ no tuvo en cuenta "el alto riesgo político social del milenarismo y parezca considerarlo más bien como una doctrina corrientemente aceptada durante la Edad Media". ${ }^{15}$

Ahora bien, uno de los problemas que veo en la historiografía, en ambos sectores, es que directa o indirectamente se basaron en el trabajo de Cohn para explicar parte de la ideología de estos minoritas, por lo que, a los que debaten el milenarismo y el joaquinismo les significa violencia, anarquía, herejía, etcétera, por la referencia que el historiador inglés hace de los movimientos milenaristas violentos de la Edad Media. No se toma en cuenta que Cohn delimita su investigación al milenarismo que se produjo en las clases más desfavorecidas de la sociedad, y efectivamente este "milenarismo fue violento, anárquico, y a veces revolucionario". ${ }^{16}$ Asimismo, él advierte de lo complejo del término milenarismo, ya que no sólo se aplica en su acepción tradicional, sino como un tipo de salvacionismo, y es así como lo emplea en su trabajo. Su libro es esencial para el conocimiento de movimientos milenaristas de tendencia violenta, pero no se puede aplicar su estudio a la realidad americana con la orden franciscana porque es otro el escenario en el que se encuentran. Se podrá objetar la violencia que trajo la Conquista, pero los franciscanos combatieron lo que a su parecer era demoniaco, el culto "idolátrico" que practicaban los indios, y por eso el castigo hacia ellos era incluso necesario. Su acción en Nueva España no se puede equiparar con la violencia de los movimientos milenaristas medievales que en general eran anticlericales, descontentos con su situación social, y en ocasiones anárquicos y revolucionarios. Y si bien a lo largo de la historia franciscana hubo hermanos radicales que creían en el milenio, y que además desvirtuaron las profecías del calabrés, los franciscanos que llegaron a esta tierra no eran heréticos, ni anárquicos, ni anticlericales, y su pobreza era elegida y la de los movimientos milenaristas no.

Por lo hasta ahora mencionado, me gustaría seguir otra explicación sobre los anhelos de los "doce", sobre todo de Motolinía, para lo cual me he apoyado en La historia del paraíso de Jean Delumeau, ${ }^{17}$ quien realizó una

14 Norman Cohn, En pos del milenio (Madrid: Alianza, 1981).

${ }^{15}$ Elsa Cecilia Frost, “¿Milenarismo mitigado o marginado?”, en Memorias del Simposio de Historiografía Mexicanística (México: Universidad Nacional Autónoma de México, Instituto de Investigaciones Históricas, 1990), 77.

${ }^{16}$ Cohn, En pos, 15.

${ }^{17}$ La Historia del paraíso se compone de tres libros: el Jardín de las delicias; Mil años de Felicidad; y Qué queda del paraíso? (México: Taurus, 2003). 
investigación sobre los sueños de felicidad en Occidente. Y en este sentido ofrece una interpretación sobre el milenarismo distinta de la de Cohn: "mi óptica difiere de la de mis antecesores. Norman Cohn ha enfocado sobre todo los aspectos violentos del milenarismo. Pero éste ha sido fundamentalmente pacífico". ${ }^{18} \mathrm{El}$ historiador francés analiza las transformaciones de ese constante anhelo que tuvo el cristianismo occidental de regresar al paraíso perdido, y así, el milenio, la profecía del emperador de los últimos días, la época joaquinita, etcétera, serían algunas de las formas que tomó ese deseo de felicidad, indica Delumeau: “'La nostalgia del futuro', esta feliz fórmula que Raymond Ruyer empleó refiriéndose a las utopías, también puede aplicarse, en mi opinión, a las esperas milenaristas, e invita a relacionarlas con otra nostalgia, la del paraíso perdido..."; es "la persistente esperanza de volver a encontrar en el futuro el paraíso terrenal de los orígenes". ${ }^{19}$

Dicho lo anterior, no creo que los "doce", ni Mendieta, esperaran el reino de mil años del Apocalipsis, y tampoco veo un milenarismo violento, sólo se aplicaría en su acepción más amplia, la que esperaba un periodo de felicidad sin que durara mil años, es decir, sí veo una época escatológica puesto que fue una de las esperanzas que abrazó el cristianismo occidental y, como se dijo, ese anhelo sufrió varios cambios, incluso hasta su secularización con la idea de progreso. Así que, observo la influencia de Joaquín de Fiore y del joaquinismo, pero no como se ha querido ver, sino porque los franciscanos, desde fechas muy tempranas y hasta por lo menos mediados del siglo XVI, principalmente con Motolinía, se sintieron elegidos para participar de manera protagonista en ese periodo de felicidad antes del fin, reconociendo así la profecía de una tercera época del Espíritu Santo guiada por unos hombres espirituales. Por lo que me alejé del concepto milenarismo para utilizar el de escatología. De igual forma, me interesa resaltar las otras profecías referidas, ya que no se ha puesto la suficiente atención en estos elementos de la apocalíptica en el franciscanismo más allá del sentido ortodoxo, pues el tema es variado y complejo, además de que también fueron usadas como justificaciones político-religiosas, propagandísticas, etcétera. En la medida de lo posible pretendo mostrar en este trabajo ese aspecto del discurso franciscano; me interesa seguir a lo largo de su historia esa época de felicidad en sus diversas acepciones, y aunque con modificaciones, hay pervivencia de este anhelo. Las dos primeras partes de este

18 Delumeau, Historia del paraíso. Mil años, 21.

${ }^{19}$ Delumeau, Historia del paraíso. Mil años, 19. 
artículo recorren el camino de la apocalíptica en el franciscanismo medieval y la última parte, su continuidad con Motolinía.

La apocalíptica en el franciscanismo: siglos XIII y XIV

La penetración de la apocalíptica en los franciscanos fue gradual y su empleo no generó problemas durante la primera mitad del siglo XIII. Un minorita que sirve como ejemplo para seguir su desarrollo es Tomás de Celano (ca.1200-1260), quien presenta la vida del santo y de la orden, así como los conflictos político-religiosos de su tiempo, en perspectiva apocalíptica. ${ }^{20}$

La pobreza fue uno de los temas que dividió a la orden franciscana en dos facciones, los espirituales y los conventuales: los primeros defendiendo la pobreza extrema de Francisco de Asís, y los segundos buscando exenciones a la misma. La pobreza fue un argumento recurrente en la literatura franciscana; Celano resalta este aspecto y critica veladamente a la orden por su relajación. ${ }^{21} \mathrm{Y}$ a pesar de que Celano no era un espiritual, creo que sí hay un tono joaquinita que se relaciona con la propuesta histórica del calabrés cuando presenta a Francisco como otro Cristo, ${ }^{22}$ por lo que, si Moisés y los doce patriarcas fueron los heraldos de la primera época, y Jesús y sus apóstoles de la segunda, el santo de Asís y sus hermanos serían de la tercera. Otro tema explotado fue el de las llagas, que, se dice, le aparecieron a Francisco en el monte Alverna en 1224, donde vio a un hombre con seis alas; ${ }^{23}$ era la confirmación de su asimilación a Cristo. Francisco fue para sus hermanos una figura excepcional; por tal motivo, su pobreza y las llagas fueron leídas como un signo escatológico, eran señales de la elección de la orden como esos hombres espirituales de Joaquín de Fiore. Y Celano expone la posición apocalíptica de la orden, menciona un sueño del Santo relacionado con la profecía de Daniel, ${ }^{24}$ y creo que se puede fusionar con

${ }^{20}$ Las principales obras de Celano son: Vida primera (1228); Vida segunda (1246-1247) y Tratado de los milagros (1252-1253), en San Francisco de Asís. Escritos, biografías, documentos, 2a. ed. (Madrid: Biblioteca de Autores Cristianos, 2006).

${ }^{21}$ Celano también indica la importancia del desposorio de Francisco con la dama pobreza, véase 1 Cel., 168-169; 2 Cel., 282.

222 Cel., 372 y 373 . Otras referencias en donde Francisco es asemejado a Cristo por sus hermanos, 310 y 320.

${ }^{23} 1$ Cel., 220. El Tratado de los milagros volvería a retomar el tema de las llagas y su asimilación a Cristo, en San Francisco de Asís. Escritos, 377.

${ }^{24}$ Dn 2 29-45. 
la tercera época de Joaquín, y ambas están ligadas al recuerdo del paraíso terrenal. Dice Celano:

Me place contar aquí una visión del santo digna de recordarse. Una noche, tras larga oración, adormeciéndose poco a poco, acabó por dormirse. Su alma santa es introducida en el santuario de Dios; y ve en sueños, entre otras cosas, una señora con estas características: cabeza, de oro; pecho y brazos, de plata; vientre, de cristal, y las extremidades inferiores, de hierro; alta de estatura, de presencia fina y bien formada. Y, sin embargo, esta señora de belleza singular se cubría con un manto sórdido. Al levantarse a la mañana el bienaventurado Padre, refiere la visión al hermano Pacífico -hombre santo-, pero no le revela lo que quiera significar. ${ }^{25}$

Para Celano, la señora se refiere a Francisco, y para otros, representa a la pobreza; sin embargo, al interior del franciscanismo se dio otra interpretación que le da una orientación escatológica, ya que significa precisamente la sucesión de los tiempos que había anunciado el profeta Daniel, en donde los franciscanos serían los herederos de este tiempo escatológico antes del fin del mundo. ${ }^{26}$ Sin duda fue un sueño importante porque sería retomado por Angelo da Clareno y por Motolinía, como se verá más adelante. Más tarde Celano parece apoyar esta tesis en su Tratado de los milagros, escrito en 1253 o 1254, y encargado por Juan de Parma, reconocido joaquinita. Ahí se lee: “¿Se podrá despreciar el célebre y conocido mensaje de las dos Órdenes sin que ello alcance el gran acontecimiento que va tener lugar en breve?" ${ }^{27}$ ¿Se refería al año de 1260 ? Pues para entonces ya se había difundido que en este año iniciaría la tercera época, y cabe mencionar que en esa fecha aparecieron movimientos escatológicos como los flagelantes y los apostolici. Ahora bien, Celano integró a su cuadro apocalíptico los problemas entre el papa y el emperador. Francisco, según Celano, apoyaba a la institución papal en detrimento del poder secular, ${ }^{28}$ y la dirección de la cristiandad y la supremacía deberían estar en sus manos, retomando las palabras de un solo rebaño y un solo pastor. ${ }^{29}$ Por el contrario, presenta al emperador Federico II con atributos negativos, manifestación del mal, de la crueldad

252 Cel., 297.

262 Cel., 297.

27 Tratado de los milagros, 376. Creo que las dos órdenes son los franciscanos y los dominicos.

281 Cel., 190-191.

291 Cel., 224. 
y de la violencia; es exhibido como un jinete del Apocalipsis de san Juan, pues por sus acciones Federico II trajo guerra, muerte, hambre, mostrado todo en un contexto de desolación, con sentido apocalíptico. ${ }^{30}$

La crítica a la pobreza y su asociación a las profecías de Joaquín, trajeron el recrudecimiento de las relaciones internas de la orden y también con otros actores, y esto ocurrió hacia la segunda mitad del siglo xiII en la Universidad de París. ${ }^{31}$

Varios fueron los motivos que el clero secular argumentó en contra de las órdenes mendicantes; por un lado, no entendían su nueva manera de ejercer la pastoral y el prestigio que iban adquiriendo, y por otro, criticaban su falta de adhesión a la institución por no apoyar las huelgas de 1229 y 1253 que se suscitaron por conflictos entre el estudiantado y la policía. Por lo anterior, el clero secular cuestionó el lugar que ocupaban las órdenes mendicantes en la estructura eclesial. ${ }^{32}$

Esta agresión fue combatida en un primer momento por el franciscano Gerardo de Borgo san Donnino, ${ }^{33}$ quien en 1254 redactó su Liber introductorium in evangelium aeternum con el objetivo de defender a su orden, y la justificación que ofreció tenía que ver con que ellos habían sido anunciados por Joaquín de Fiore como los hombres espirituales que guiarían la tercera época del Espíritu Santo, misma que iniciara en el año 1260, no sin antes pasar por las tribulaciones correspondientes. Y con su propuesta no sólo justificaba el lugar que ocupaban sus hermanos dentro del aparato eclesiológico, sino dentro de la historia. Gerardo no logró dar fin al asunto; por el contrario, lo radicalizó, y no sólo con el clero secular, sino además con el papado y con su misma orden. En 1255 el Liber fue condenado por Roma y Borgo fue expulsado de la Universidad, pero las obras de Joaquín no sufrieron censura alguna. La división entre espirituales y conventuales se hizo más profunda, y el ministro general, Juan de Parma, terminó dimitiendo en 1250 ya que era seguidor, como Borgo, del calabrés, aunque más tarde fue absuelto por Adriano V. ${ }^{34}$ Y Buenaventura sería el encargado de juzgar a los espirituales. ${ }^{35}$

302 Cel., 281.

${ }^{31}$ Para el tema de la Universidad, me basé principalmente en Saranyana, Joaquín de Fiore.

${ }^{32}$ Saranyana, Joaquín de Fiore, 56.

${ }^{33}$ Véase Saranyana, Joaquín de Fiore, 57-64.

${ }^{34}$ Saranyana, Joaquín de Fiore, 60.

${ }^{35}$ Más tarde, Clareno y las Florecillas harían referencia a este episodio. Abordan una profecía de Jacobo de Masa, quien, mediante la figura de un árbol, describe la persecución 
En 1260 el Capítulo General ordenó a Buenaventura redactar una biografía del santo con la intención de que fuera la única interpretación de su vida, lo que dio como resultado la Leyenda mayor. Asimismo, mandó destruir las biografías existentes por la exaltación apocalíptica que del santo y de la orden hacían. Ahora bien, la Leyenda mayor, a decir de Le Goff: “...es tendenciosa y fantasiosa [...] este san Francisco de medias tintas se acerca más al de los conventuales que al de los espirituales". ${ }^{36}$ Pero hay un aspecto polémico a pesar de lo ocurrido con los espirituales, pues presenta al santo de manera apocalíptica, indica Buenaventura: "Se puede creer con fundamento que Francisco fue prefigurado en aquel ángel que subía del Oriente llevando impreso el sello de Dios vivo [...]. En efecto, al abrirse el sexto sello —dice Juan en el Apocalipsis-, vio otro ángel que subía del Oriente llevando el sello de Dios Vivo. ${ }^{37}$

Como se observa en la cita anterior, Buenaventura hace referencia a las llagas de Francisco. Creo que la consecuencia de esto sería, siguiendo el Apocalipsis de san Juan, que la orden franciscana tenía la misión de marcar a los 144000 elegidos. ${ }^{38}$ Además que esta identificación que hace del santo lo uniría a los espirituales. En este sentido, existe un debate en torno a la posible influencia del calabrés en la concepción histórica bonaventuriana, puesto que, una vez tranquilizado el problema con los espirituales, Buenaventura desarrolló una teología de la historia de corte joaquinita, ${ }^{39}$ incluso Ratzinger reconoce que hay influjo también de los espirituales en Buenaventura. ${ }^{40}$

Sin embargo, el conflicto con los espirituales estaba lejos de estar resuelto, sólo era necesario un motivo para hacer resurgir los reclamos, es decir, la defensa de la pobreza unida a una expectativa escatológica. El motivo lo dio el Segundo Concilio de Lyon (1274) ${ }^{41}$ cuando resolvió otorgar en

que Buenaventura llevó a cabo en contra de los espirituales; es una crítica a Buenaventura y una apología a Parma y sus hermanos y de la renovación de la orden. Véase Angelo Clareno, A Chronicle or History of the Seven Tribulations of the Order of Brother Minor (New York: Franciscan Institute Publications, The Franciscan Institute St. Bonaventure, 2005), 118-120. Florecillas de San Francisco y sus compañeros, en San Francisco de Asís. Escritos.

${ }^{36}$ Jacques Le Goff, San Francisco de Asís (Madrid: Akal, 2003), 29.

37 Buenaventura, Leyenda mayor, 396-397.

${ }^{38}$ Ap 74 . El marcado de los elegidos también se encuentra en Motolinía, como se verá más adelante.

${ }^{39}$ Véase Joseph Ratzinger, La teología de la historia de san Buenaventura (Madrid: Encuentro, 2004).

${ }^{40}$ Ratzinger, La teología de la historia, 167-168.

${ }^{41}$ Hubert Jedin, Breve historia de los concilios, 3a. ed. (Barcelona: Herder, 1963), 72-73. 
propiedad los bienes que hasta entonces la orden franciscana sólo tenía en uso, dado que, según los minoritas, "sólo les corresponde el llamado simple uso. Esta precisión conceptual-jurídica, que garantiza la posibilidad, digamos legal de la vida franciscana en pobreza", es el "llamado usus pauper; es decir el de quien profesa y vive en una pobreza radical y efectiva". ${ }^{2}$

Los franciscanos argumentaron que Jesús y sus apóstoles habían carecido de posesiones individuales y colectivas, y bajo este esquema de extrema pobreza se habían regido en sus inicios. Pero, sin duda alguna, el tema de la pobreza se volvió más conflictivo con Juan XXII; por lo que, adelantándose a la resolución papal, los minoritas concluyeron en el Capítulo de Perusa (1322) la pobreza total y absoluta de Jesús y sus apóstoles. ${ }^{43}$ La respuesta papal no fue favorable a esta resolución, y mediante la bula cum inter nonnulos la declaró herética. ${ }^{44} \mathrm{El}$ ministro general Michele da Cesena le propuso a Ockham estudiar el asunto. Y este último acusó de hereje al papa por la pobreza, y también por la supremacía universal. ${ }^{45}$ En este contexto varios franciscanos tomaron partido a favor del emperador Luis IV de Baviera.

Ahora bien, fueron tres franciscanos espirituales los que sobresalieron como líderes: Pedro Juan Olivi (1248-1298), Ubertino da Casale (12591330) y Angelo da Clareno (ca. 1248-1337). Ellos ejercieron un tipo de activismo que unía la defensa de la pobreza con una expectativa escatológica. Se hacían mano de la periodización tradicional y de la joaquinita, y así la felicidad sería en un futuro intrahistórico. ${ }^{46}$ Identificaban a Francisco como el otro Cristo y como el ángel del sexto sello, ${ }^{47}$ y a ellos como los hombres espirituales, y la pobreza era un signo de ello. ${ }^{48}$ De igual forma, tenían la esperanza en un papa angelical ante la corrupción imperante en la Iglesia, y Celestino V (1294) por un momento avivó esta esperanza.

En cuanto a Angelo da Clareno cabe decir que su postura escatológica la reforzó con la profecía del sueño de Daniel, que ya había sido referida

${ }^{42}$ Esteban Peña Eguren, La filosofía política de Guillermo de Ockham. Relación entre potestad civil y potestad eclesiástica. Estudio sobre el "Dialogus, pars III" (Madrid: Encuentro, 2005), 158.

${ }^{43}$ Peña Eguren, La filosofía política, 161.

${ }^{44}$ Peña Eguren, La filosofía política, 162.

45 Véase Guillermo de Ockham, Sobre el gobierno tiránico del papa, 2a. ed. (Madrid: Tecnos, 2008).

${ }^{46}$ Ubertino of Casale, "The Tree of the Crucified Life of Jesus", en Bernard McGinn, Visions of the End. Apocalyptic Traditions in the Middle Ages (New York: Columbia University Press, 1979), 212-215.

47 Peter Olivi, “Commentary on Revelation”, en McGinn, Visions, 208.

${ }^{48}$ McGinn, Visions, 203. 
por Celano, pero con modificaciones. En Clareno la estatua es la figura de un ángel que se le reveló a Francisco mientras oraba, y tenía cabeza de oro, brazos y pecho de plata, estómago de bronce, piernas de hierro y sus pies eran de tierra y barro, y se cubría sus hombros con un paño barato y áspero. El ángel le dijo a Francisco que la forma que había adoptado significaba el principio, el periodo intermedio y el fin de la orden, y le proporcionó la interpretación de su aspecto y su relación directa con la orden. La explicación de los materiales con los que está compuesta, el oro, la plata, etcétera, es decreciente; Francisco representa la cabeza de oro de la figura que se va degradando conforme los hermanos van abandonando la pobreza. ${ }^{49}$

Ahora bien, Clareno también mencionó a Celestino V, su amor por la pobreza y el apoyo que les brindó. ${ }^{50}$ Este papa había sido identificado como el papa angelical, y fue en el grupo de Clareno donde probablemente se redactaron las profecías papales; sin embargo, ante su renuncia encuadra este evento desde una perspectiva escatológica. Las tribulaciones quinta, y sobre todo la sexta, son las del tiempo de Clareno, porque según él son eventos contemporáneos, hay un recrudecimiento de las persecuciones, y la serpiente antigua sería liberada pronto para corromper el evangelio y a las personas; ${ }^{51}$ es el tiempo del Anticristo, un tiempo de grandes tribulaciones, ${ }^{52}$ pero se ofrece esperanza ya que era antesala de una nueva época. ${ }^{53}$

La influencia apocalíptica en el franciscanismo de la península ibérica

En un principio los temas apocalípticos en la península ibérica estuvieron orientados a la preocupación por el fin de los tiempos, y la presencia musulmana animó esta inquietud, ${ }^{54}$ pero a partir del siglo XIII la apocalíptica se enriqueció, y las Coronas de Castilla y Aragón, y después la de Portugal, se vieron influidas de lo que ocurría en el resto de Occidente, y también por la influencia de los franciscanos que contribuyeron con las profecías de

${ }^{49}$ Clareno, A Chronicle, 22-24.

${ }^{50}$ Clareno, A Chronicle, 155-158.

${ }^{51}$ Clareno, A Chronicle, 192.

52 Clareno, A Chronicle, 195.

${ }^{53}$ Clareno, A Chronicle, 194-195.

${ }^{54}$ Probablemente el beato de Liébana (siglo viıI) sea el ejemplo más representativo, pues propuso que aproximadamente en el año 800 se cumplirían los seis mil años de la historia humana. Véase: beato de Liébana, Obras completas y complementarias, Maior, n. 76 (Madrid: Biblioteca de Autores Cristianos, 2004), libro IV, 369. 
Joaquín de Fiore, la de un emperador de los últimos días, y la de un papa angelical.

En Castilla se difundió literatura franciscana de tendencia espiritual, ya que en los siglos XIV y XV circularon las fontes franciscani, recopilaciones de fuentes franciscanas primitivas y de otros escritos que se produjeron más tarde. ${ }^{55}$ En éstas se abordaban diversos temas espirituales, como la estigmatización de Francisco, la relevancia de la orden en su misión evangelizadora, las tribulaciones que enfrentarían, así como, la pobreza. Asimismo, los franciscanos de Cataluña, Valencia y Mallorca, recibieron el influjo de los espirituales, ${ }^{56} \mathrm{y}$ en este sentido hay que mencionar la importancia que desempeñó el Mediterráneo occidental como diseminador de ideas apocalípticas, ligadas a cierta heterodoxia, pues a pesar de que esta zona vivió un crecimiento económico había pobreza en diversos sectores de la sociedad, lo cual generaba críticas. Las alianzas matrimoniales de igual forma favorecieron a la apocalíptica; por ejemplo, con la unión de Pedro III de Aragón con Constanza II de Sicilia, Aragón heredaba la tradición mesiánica de los Hohenstaufen, y esto ayudaba a su justificación expansionista por el Mediterráneo, ${ }^{57}$ aunada a profecías que se referían a la supremacía de Aragón, y la contribución de los franciscanos espirituales, a los que la Corona protegía. ${ }^{58}$

En Aragón un personaje que cobró relevancia fue Arnaldo de Vilanova (1238-1311), un terciario franciscano de orientación joaquinita, quien contribuyó enormemente a la reinterpretación de la profecía del emperador de los últimos días, pues hasta entonces los destinatarios habían sido Francia y Alemania, y él la asignó a Aragón, indica Vilanova:

España, que alimenta la depravación mahometana, será desgarrada. Sus reinos se levantarán unos contra otros [...] hasta que un vespertilión (murciélago) devore los mosquitos del país y, sometiendo a África y descalabrando a la bestia [musul-

55 Juana María Arcelus Ulibarrena, "Alonso de Mella en clave de lenguaje ortodoxo: tribulaciones vs. perfecta alegría”, Clío \& Crimen. Revista del Centro de Historia del Crimen de Durango, n. 8 (2011): 461-465.

56 José García Oro, Francisco de Asís en la España medieval (Burgos: Aldecoa, 1988), 478-479.

${ }^{57}$ Bernardo Bayona Aznar, "Las lealtades de Francesc Eiximenis (1328?-1409) en el cisma y su doctrina de poder", en Doctrinas y relaciones de poder en el cisma de Occidente y en la época conciliar (1378-1449) (Zaragoza: Prensas de la Universidad de Zaragoza, 2013), 114-115.

58 Bayona Aznar, “Las lealtades de Francesc Eiximenis”, 115. 
mana], encabece la monarquía universal y humille a los habitantes del Nilo. Después de lo cual el Hijo de la perdición [el Anticristo] surgirá repentinamente para pasar a los mortales por el tamiz. ${ }^{59}$

Y el vespertilión era ya una nueva interpretación del emperador de los últimos días. La influencia de Vilanova fue grande, incluso, Fernando el Católico sería saludado como el vespertilión. ${ }^{60}$

Otro minorita que ejerció gran influjo en Aragón fue Francesc Eiximenis (1330-1409), un pensador de tendencia joaquinita, que de igual forma puso profecías políticas al servicio de la Corona para apoyar su expansión en el Mediterráneo, razón por la cual retomó el vespertilión de Vilanova para relacionarlo con una monarquía mesiánica universal que acabaría con el islam. ${ }^{61}$ Asimismo, se hizo eco de la profecía papal, ya que ambos repararían a la cristiandad. Sin embargo, la teoría política de Eiximenis es compleja y ambigua, porque a pesar del mesianismo atribuido a Aragón era un defensor de la teocracia, y la supremacía del mundo debía estar en manos del papa. ${ }^{62}$ En este mismo sentido, en una carta dedicada al jurado de Valencia, alude a la herencia que Dios otorgó a los apóstoles sin mediación de alguna autoridad civil. ${ }^{63}$ Pese a lo anterior, supo acomodar sus dos lealtades. La obra de Eiximenis fue traducida y difundida en la corte de los Reyes Católicos, y recuperada por sus hermanos, incluso la citó Mendieta en su Historia eclesiástica indiana. ${ }^{64}$

Ahora bien, en el siglo Xv surgió un movimiento radical en Castilla llamado "los herejes de Durango", y liderado por el franciscano Alonso de Mella, ${ }^{65}$ originario de Zamora, Castilla. Mella llegó a Durango entre los años de 1437 y 1440 junto a otros hermanos, disidentes de la Corona de Aragón.

${ }^{59}$ Citado en Delumeau, Historia del paraíso. Mil, 359.

${ }^{60}$ Delumeau, Historia del paraíso. Mil, 360.

${ }^{61}$ Bayona Aznar, "Las lealtades de Francesc Eiximenis", 117.

${ }^{62}$ Eiximenis, Dotze vi, citado en Bayona Aznar, "Las lealtades de Francesc Eiximenis", 143-144.

${ }^{63}$ Francesc Eiximenis, Gobierno de la República, ed. de Miquel Castellano i Arolas (València, Fil d'Aram, 2009), 21.

${ }^{64}$ Gerónimo de Mendieta, Historia eclesiástica indiana, Cien de México (México: Consejo Nacional para la Cultura y las Artes, 2002), libro 1, cap. v, 125.

${ }^{65}$ Para los llamados herejes de Durango me baso principalmente en: Iñaki Bazán Díaz, "Formas de disidencia frente a la Iglesia medieval: los herejes de Durango", Norba, Revista de Historia, v. 20 (2007); "Los herejes de Durango: un interrogante historiográfico por responder”, Clío \& Crimen. Revista del Centro de Historia del Crimen de Durango, n. 1 (2004): 261-299. 
Se ha intentado establecer la filiación ideológica de este grupo, se les ha relacionado con Joaquín de Fiore, los espirituales, los fraticelli, con la herejía del libre espíritu, con los alumbrados, etcétera, ${ }^{66}$ pero la influencia apocalíptica pudo haber llegado a ellos, de igual forma, por medio de las fontes franciscani. ${ }^{67}$ Esta "herejía" tenía esperanza no sólo en la reforma de su orden, sino también de la Iglesia, y en la espera de la edad del Espíritu Santo $^{68}$ y en la carta que Mella escribió al rey se observa el influjo del abad calabrés y de los espirituales. ${ }^{69}$ Mella se creía un elegido para revelar lo oculto, ya que la revelación de la Escritura no se había completado, y como el abad, creyó que la revelación de la misma era progresiva. Para Mella, sus hermanos tendrían una participación decisiva en este aspecto, y su verdad debía conocerse en la antesala de la época del Espíritu Santo. Mella, por tanto, creía que acabaría una época y vendría otra.

A pesar de su influencia en el duranguesado, la "herejía" fue combatida pronto por la autoridad eclesiástica, la Corona y la autoridad local. ${ }^{70} \mathrm{La}$ persecución se dio de 1441 a 1444 cuando se excomulgó y se quemó a los "herejes". ${ }^{71}$ Mella huyó y murió más tarde, desafortunadamente no se sabe la fecha, pero fue después de 1455 , año en que redactó su carta. ${ }^{72}$ Y aunque sus proposiciones se volvieron radicales, las tesis joaquinitas pervivieron sin radicalidad en la observancia del siglo XV y XVI.

Ahora bien, los intentos de reforma han estado presentes a lo largo de la historia cristiana, y el regreso al cristianismo primitivo ha sido uno

${ }^{66}$ Robert Muro, “Durango, 1442. Sueño efímero de salvación”, Milenarismos y milenaristas en la Europa Medieval, IX Semana de Estudios Medievales de Nájera (Nájera: Instituto de Estudios Riojanos, 1999); Arcelus, "Alfonso”; Ernesto García Fernández, "Expresiones heréticas en la España medieval. Los herejes de Durango", Cristianismo marginado: rebeldes, excluidos, perseguidos. II. Del año 1000 al año 1500. Actas del XII Seminario sobe Historia del Monacato en Aguilar de Campoo (Palencia), del 3 al 6 de agosto de 1998, ed. de José Ángel García de Cortázar (Madrid: Fundación Santa María la Real; Aguilar de Campoo, Madrid: Polifemo, 1999), etcétera.

${ }^{67}$ Arcelus, "Alonso", 468.

68 Bazán Díaz, "Formas”, 47-48.

${ }^{69}$ Desafortunadamente sólo existe una fuente directa de este movimiento; es una carta que en 1455 escribió Mella al rey de Castilla. Para la carta, véase Arcelus, "Alonso", quien a su vez se basó en Iñaki Bazán Díaz, Los herejes de Durango y la búsqueda del Espíritu Santo en el siglo XV (Durango, España: Museo de Arte e Historia de Durango, 2007), 681-686.

${ }^{70}$ Iñaki Reguera, "La Inquisición en el País Vasco. El periodo fundacional”, Clío \& Crimen. Revista del Centro de Historia del Crimen de Durango, n. 2 (2005), 252.

${ }^{71}$ Bazán Díaz, “Formas”, 31.

72 Bazán Díaz, “Formas”, 50. 
de los objetivos de los sectores críticos. En los siglos XV y XVI había un importante clima de renovación espiritual, movimientos como la Devotio Moderna, la Philosophia Christi y las corrientes humanísticas de la época contribuyeron a cambios dentro de la Iglesia, pero también producirían la ruptura, como lo fue la Reforma protestante. Y la península ibérica no sería la excepción.

La unidad religiosa era un proyecto sustancial para los Reyes Católicos, y en este sentido, en 1492 se expulsaba a los judíos, se tomaba Granada y se llegaba a las Indias. Asimismo, emprendieron la reforma religiosa en sus respectivos reinos, sin olvidar las motivaciones políticas y económicas que había de por medio. ${ }^{73}$ Hay que mencionar que esta política los ayudó a su posicionamiento mesiánico, y las profecías, de igual forma, fueron usadas como instrumentos de propaganda política, ${ }^{74}$ sin soslayar la probabilidad de un verdadero sentimiento religioso. Pero quien más se benefició fue Fernando, pues a decir de Ladero Quesada: "alrededor del rey Fernando se acentuó la propaganda en torno al 'monarca carismático', llamado a dirigir la 'república cristiana', a aniquilar al islam y recuperar la 'Casa Santa' de Jerusalén...." ${ }^{75}$ Joan Alemany, conocido igualmente como Juan de Unay, ${ }^{76}$ se refirió a la profecía del emperador de los últimos días como el encubierto, y al papa como el nuevo David, y en su obra hay un protagonismo mesiánico a favor de Aragón. Alonso de Jaén, quien retomó el vespertilión de Vilanova, Martín Martínez Ampiés, Lucio Marineo Sículo e incluso la beata del Barco de Ávila son algunos de los propagandistas de Fernando y quienes pusieron a circular profecías a su favor. ${ }^{77}$ De igual forma el rey se

${ }^{73}$ José García Oro, Cisneros y la reforma del clero español en tiempos de los Reyes Católicos (Madrid: Consejo Superior de Investigaciones Científicas, Instituto Jerónimo Zurita, Biblioteca Reyes Católicos, 1971), 351-352.

${ }^{74}$ Para la propagada política, véase Ana Isabel Carrasco, "Discurso político y propaganda en la corte de los Reyes Católicos (1474-148)”, tesis doctoral (Madrid: Universidad Complutense de Madrid, Departamento de Historia Medieval, 2003), 51; José Manuel Nieto Soria, “Apología y propaganda en la realeza en los cancioneros castellanos del siglo xv. Diseño literario de un modelo político”, La España Medieval, n. 11 (1998).

${ }^{75}$ Miguel Ángel Ladero Quesada, La España de los Reyes Católicos, 4a. ed. (Madrid: Alianza Editorial, 2014), 147.

${ }^{76}$ Minorita, que decía pertenecer a la orden del Sancti Spiritus, por lo que se ha pensado que es una referencia a su adscripción ideológica joaquinita proveniente de Vilanova, en María Isabel Toro, "Milenarismo y profecía en el siglo xv: la tradición del libro de Unay en la península ibérica”, Península: Revista de Estudios Ibéricos, n. 0 (2003), 30.

77 Véase, por ejemplo, el estudio de Juan Gil, “El nudo gordiano y Fernando el Católico”, Habis, n. 16 (Universidad de Sevilla, 1985). 
hizo mano de profecías de Llul, Rocatallada y Eximenis. Y este mesianismo llegaría a Carlos V.

Por su parte, los franciscanos también promovieron la reforma, y cabe mencionar que se dio a principios del siglo Xv en Castilla la reforma villacreciana con la intención de un franciscanismo más pobre. Ahora bien, Francisco Jiménez de Cisneros impulsó la reforma en su orden y en algunos casos iba unida a una expectativa mesiánica. La labor intelectual de Cisneros fue muy relevante, y además de impulsar las corrientes humanísticas y reformadoras de la época, era cercano a círculos espirituales, pues a pesar de su posición política, era un eremita que se preocupaba por la apocalíptica. De igual forma, hay que resaltar sus anhelos de cruzada, para Cisneros fue importante la toma de Granada, la conquista de Orán y las Indias, había en él un profetismo mesiánico. Hay que señalar su cercanía a grupos de tendencia espiritualista y profética, como beatas, frailes y monjas, que incluso estuvieron bajo su amparo. ${ }^{78} \mathrm{Y}$ hacia $1511-1512$ fue el centro de esperanzas mesiánicas, sobre todo, para ocupar el papado, y así cumplir el viejo sueño de un pastor y un solo rebaño en una nueva era. ${ }^{79}$

La reforma franciscana de Cisneros enfrentó problemas entre los conventuales y los observantes, sin olvidar que tanto él como los reyes buscaban que la orden fuera solamente observante. ${ }^{80}$ Aunque a partir de 1500 se pretendía ya la reforma total de los franciscanos y no sólo los de España. ${ }^{81}$ El conflicto entre las dos ramas llegó al Capítulo General de la orden celebrado en Roma en 1517, pero este mismo año el papa León X, por medio de la ite vos, ordenó que los grupos reformados pasaran a formar parte de la observancia, y esta decisión ayudó a Cisneros en España.

Pero hay que mencionar que se dio otra reforma franciscana en la península ibérica paralela a la de Cisneros, y de ella salieron los primeros evangelizadores de América, y se le reconoce un "fuerte espíritu milenario". ${ }^{2}$

${ }^{78}$ José García Oro, Cisneros. Un cardenal reformista en el trono de España (1436-1517) (Madrid: La Esfera de los Libros, 2005), 179.

${ }^{79}$ García Oro, Cisneros, 189.

${ }^{80}$ Para un estudio del franciscanismo en la península ibérica de tipo conventual, véase García Oro, Francisco de Asís.

${ }^{81}$ Antonio Rubial, La hermana pobreza. El franciscanismo: de la Edad Media a la evangelización novohispana (México: Universidad Nacional Autónoma de México, Facultad de Filosofía y Letras, 2006), 45.

${ }^{82}$ Mercedes Serna y Bernat Castany, "Estudio introductorio”, en Historia de los indios de la Nueva España, de Toribio de Benavente, Motolinía (Madrid: Real Academia Española, 
Esta reforma, conocida como guadalupenses o capuchos, fue promovida por fray Juan de la Puebla y fray Juan de Guadalupe, quienes también defendían y promovían la pobreza extrema. Una vez muerto Juan de la Puebla, su discípulo Juan de Guadalupe creó una nueva custodia sometiéndose a los conventuales. En Extremadura fundó conventos eremitorios en Salvaleón, Trujillo, Alconche, etcétera, y con ellos se crearon dos custodias, la del Santo Evangelio, que era dirigida por Guadalupe, y la segunda la de Nuestra Señora de la Luz. ${ }^{83} \mathrm{Y}$ a pesar de que estaban unidos a los conventuales, llevaban una vida de extrema pobreza que competía con la observancia.

Pese a esto, como indiqué, con la ite vos (1517) quedaron absorbidos por la observancia. Posteriormente el Santo Evangelio se convertiría en provincia, la de Extremadura, con la advocación de san Gabriel.$^{84}$ Eran hombres con una firme convicción apostólica y defensores de la extrema pobreza y en ocasiones con ideas apocalípticas joaquinitas, y de entre ellos salieron los evangelizadores de América, los llamados "doce”. A decir de Serna y Castany: "dicha reforma defendía una renovación espiritual ligada con las teorías milenaristas del fraile calabrés, quien cifraba todas sus esperanzas de redención de la humanidad en una tercera edad [...] que identificaba con el Millenium apocalíptico". ${ }^{55} \mathrm{Y}$ esta influencia joaquinita "en Motolinía es incuestionable", 86 aunque tercera época y milenio eran cosas distintas para Joaquín de Fiore.

\section{La apocalíptica franciscana en América}

El Nuevo Mundo animó las creencias apocalípticas. La empresa colombina no sólo pretendía abrir una ruta comercial hacia Oriente, sino también recuperar Jerusalén y llevar el cristianismo a todas partes; en este proyecto había un propósito mesiánico, y según Colón, que tenía influencia de los franciscanos y acceso a literatura pseudojoaquinita, había llegado el momento de recuperar el santo sepulcro, según lo había indicado Joaquín de

Centro para la Edición de los Clásicos Españoles, 2014), 11. Los autores siguen a Baudot en este tema.

${ }^{83}$ García Oro, Cisneros, 232 y 233.

${ }^{84}$ Rubial García, La hermana, 66.

${ }^{85}$ Serna y Castany, "Estudio introductorio", 64.

${ }^{86}$ Serna y Castany, "Estudio introductorio", 64. 
Fiore, y la empresa estaría a cargo de un español, ${ }^{87}$ pues era el nuevo pueblo elegido. Se observa, así, un mesianismo oficial. ${ }^{88}$ El mismo Colón se consideraba "el mensajero del nuevo cielo y tierra". ${ }^{89}$ Y Delumeau se pregunta sobre Colón, "pero ¿de qué escatología se trataba exactamente? ¿De la que preveía un próximo fin del mundo o de la que intercalaba antes del juicio final un tiempo de paz y de felicidad sobre la tierra?", ${ }^{90}$ y responde que seguía esa tradición que esperaba una etapa: "de paz, de reconciliación y de conversión general de toda la humanidad, habiendo sido eliminado previamente el peligro musulmán". ${ }^{91}$ Asimismo, cabe mencionar que al tomar una ruta distinta en su tercer viaje (1498) creyó reconocer el lugar donde se ubicaba el paraíso terrenal, aunque inaccesible para los humanos. ${ }^{92}$

La evangelización de los nativos ocupó un lugar importante en la política religiosa de la Corona; era necesario integrarlos a la grey cristiana, y en estos momentos la orden más calificada para la evangelización era la franciscana, y no sólo porque tenía experiencia misional, sino porque acaban de pasar por una reforma. Como se ha visto, el franciscanismo a lo largo de su historia participó del anhelo escatológico, y América les permitía la posibilidad de materializarlo. Los llamados "doce" franciscanos llegaron a la Nueva España de manera formal y organizada en 1524, para desterrar la idolatría e implantar el cristianismo. Bernal Díaz del Castillo habla de cómo Cortés recibió a la primera misión de los doce:

cuando Cortés supo que llegaban, se apeó del caballo, y todos nosotros juntamente con él; y ya que nos encontramos con los reverendos religiosos, el primero que se arrodilló delante de fray Martín de Valencia y le fue a besar las manos fue Cortés,

87 "Carta del Almirante al rey y á la reina”, en Relaciones y cartas de Cristóbal Colón (Madrid: Librería de la viuda de Hernando, 1892), 334 (Libro de las profecías).

${ }^{88}$ Alain Milhou, Colón y su mentalidad mesiánica en el ambiente franciscanista español (Valladolid: Casa-Museo Colón; Valladolid: Seminario Americanista de la Universidad de Valladolid, 1983), 212.

${ }^{89}$ Milhou, Colón y su mentalidad, 252. Véase Ap 21.

${ }^{90}$ Delumeau, Historia, 371.

${ }^{91}$ Delumeau, Historia, 371.

${ }^{92}$ Copia de la "Carta de relación del tercer viaje”, realizada por Bartolomé de las Casas, citado en Jesús Varela y María Montserrat León Guerrero, Colón, su tesis "pezonoidal" del globo terráqueo y el itinerario del tercer viaje, la fantasía del paraíso terrenal (Valladolid: Seminario Iberoamericano de Descubrimientos y Cartografía; Valladolid: Universidad de Valladolid, Instituto Interuniversitario de Estudios de Iberoamérica y Portugal, 2002), 112-116. 
y no lo consintió, y le besó los hábitos y a todos los más religiosos, y así hicimos todos los más capitanes y soldados que allí íbamos $[\ldots] .{ }^{93}$

Estos franciscanos se reconocieron como actores de primer orden para la evangelización, por lo que creo que esta noción de elección se puede relacionar con los hombres espirituales de Joaquín de Fiore. Del Val ha estudiado la importancia de los duo viri en la península ibérica, tanto por la influencia del Libro de las Conformidades de Bartolomé de Pisa, como por el Floreto de san Francisco, ${ }^{94}$ aunque la línea de continuidad de la influencia de Joaquín es desde el mismo siglo xiII. Asimismo, en la Instrucción y la Obediencia, que el ministro general Francisco de los Ángeles dio a los "doce", se observa la trascendencia de los hombres espirituales. En su misión a las Indias estos franciscanos debían imitar a Cristo y a sus apóstoles, como lo hicieran Francisco y sus hermanos, que era imagen de la primera. ${ }^{95}$ Era una misión apostólica, pero creo que igualmente era una concordancia. Hay una preocupación y un interés de integrar esta empresa al cuadro apocalíptico; por eso, Francisco de los Ángeles encuadra esta misión en los últimos tiempos. ${ }^{96}$

Ahora bien, antes de abordar a Motolinía, hay que decir algunas palabras sobre fray Martín de Valencia. ${ }^{97}$ En primer lugar hay que resaltar que era un amante de la extrema pobreza. Su biógrafo, Francisco Jiménez, decía que "en verle, me fue una gran rreprensión ynterior, así en la pobreza como en la aspereza de su ábito y lo demás que me pareçió, que vía otro sant Francisco, y se me rrepresentó su cara como de un apóstol". ${ }^{98}$ Su pobreza $\mathrm{y}$ vida de mortificaciones igualmente fue advertida por Motolinía ${ }^{99}$ y por Mendieta. ${ }^{100}$ Valencia era un místico, un asceta que hacía uso del cilicio, y

${ }^{93}$ Bernal Díaz del Castillo, Historia verdadera de la conquista de la Nueva España, "Sepan cuantos...”, n. 5, 27a. ed. (México: Porrúa, 2017), cap. ClXXI, 450.

${ }^{94}$ José María Alonso del Val, "El milenarismo en la primera evangelización de los franciscanos en América”, en Milenarismos, 367.

${ }^{95}$ Instrucción, en Mendieta, Historia eclesiástica, 339.

${ }^{96}$ Instrucción, en Mendieta, Historia eclesiástica, 344.

${ }^{97}$ Sabemos de su vida principalmente por la biografía que escribió Francisco Jiménez, otro de los doce, en 1536: Jhesus, María, Franciscus. Vita fratris Martini de Valençia, véase Rubial, La hermana. Asimismo, por Motolinía y Mendieta.

98 Jiménez, “Vida de fray Martín de Valencia”, 227.

${ }^{99}$ Fray Toribio de Benavente Motolinía, Historia de los indios de la Nueva España, "Sepan cuantos...”, n. 129, 8a. ed. (México: Porrúa, 2007), tratado III, cap. 2.

${ }^{100}$ Mendieta, Historia eclesiástica, libro v. 
durante su vida padeció mortificaciones físicas y morales, así como tentaciones que afianzaron su fe; era un visionario con tendencia apocalíptica, e incluso se ha dicho que podría ser el único de ese grupo con tendencia milenarista. ${ }^{101}$ Pero creo que más que milenarista hay influencia en él de Joaquín de Fiore con esos hombres espirituales, pues según Del Val: "Fray Martín de Valencia conocía sobradamente el contenido de la profecía (de los duo viri) del abad Joaquín y fue el primer divulgador de ésta en México". ${ }^{102}$

$\mathrm{Y}$ en este mismo sentido Valencia leyó en su noviciado el Libro de las conformidades de Bartolomé de Pisa. ${ }^{103}$ Jiménez narra la visión que tuvo sobre la conversión de los infieles, ${ }^{104}$ por la cual Valencia comenzó a sentir necesidad de ir con ellos, y acudió con la beata del Barco de Ávila para saber sobre el tiempo de su visión. ${ }^{105}$ Más tarde, cuando encabezó la misión de los "doce" sabía que se cumpliría su profecía. ${ }^{106}$ Pero su anhelo escatológico no se cumplió. Valencia murió el 21 de marzo de 1534 con fama de santidad.

Motolinía y su sueño escatológico

Fray Toribio de Benavente, Motolinía (1490-1569), fue uno de los principales actores de la primera evangelización, y él, como muchos de sus hermanos desde el mismo siglo xIII, participaba de esa espera escatológica, y América representaba la posibilidad de ver materializado ese sueño. Y aunque los nativos eran una incógnita y representaban un reto, Dios los había descubierto para su salvación. La tarea más apremiante era extirpar la "idolatría” y lograr la evangelización; había que acabar con el demonio para que pudieran vivir, tanto indios como frailes, en una época de felicidad antes del fin del mundo.

El castigo a los indios por sus "idolatrías" vino por medio de diez plagas que Dios envió. Motolinía las expone en su Historia y en los Memoriales,

101 Canedo, "Milenarismo", 154.

102 Del Val, “El milenarismo”, 376.

103 Jiménez, "Vida de fray Martín de Valencia”, 225. Véase también Mendieta, Historia eclesiástica, libro v, cap. 1, 263.

104 Jiménez, "Vida de fray Martín de Valencia”, 232 y 233. Y esta visión fue retomada por Motolinía y Mendieta.

105 Jiménez, "Vida de fray Martín de Valencia”, 235; véase Motolinía, Historia de los indios, tratado III, cap. 2, 175 y 176.

106 Jiménez, "Vida de fray Martín de Valencia”, 233. 
pero es en este último donde trata de relacionarlas una a una con las diez plagas que Dios envió a Egipto por la obstinación del faraón al no liberar a Israel. ${ }^{107}$ En este sentido Motolinía indica que "Hirió Dios esta tierra con diez plagas muy crueles por la dureza e obstinaçión de sus moradores y por tener cautivas las hijas de Sión, esto es, sus propias ánimas so el yugo del Faraón". ${ }^{108}$ Estas plagas trajeron muerte, hambre, enfermedad, esclavitud, problemas, etcétera, y en ellas hay un tono apocalíptico importante. Motolinía advierte lo difícil de relacionarlas con las de Egipto, pero reconoce que las de Nueva España fueron más dolorosas, pues "Por los pecados destos naturales fue Dios mouido a yra contra ellos, y los castigó, como dicho es, e su saña e yra se ýndignó contra ellos". ${ }^{109}$

La primera plaga fue la viruela, que vino acompañada de hambre y sarampión, y la relaciona, como se dijo, con la primera plaga de Egipto:

Esta primera plaga fue bien semejante a la de Egipto [...]. Digamos que esta tierra como otra Egipto en ella el agua fue convertida en sangre de aquella cruel enfermedad de la qual desde los menores hasta los mayores murieron casi la mitad. Y el agua fue hecha hedionda, quando muchos morían, que no los pudiendo enterrar, hedían por todas partes. Y ansí como en esta tierra auía mucha crueldad y derramamiento de sangre humana ofreçida al demonio, angel de Satanas, bien ansí el segundo angel derramó sobre ella su vaso como sobre otra mar amarga fluctuosa, y fue hecho el mar, esto es, esta tierra, como sangre de muerto. ${ }^{110}$

La segunda plaga fue la Conquista de México, y a diferencia de la anterior donde murieron los pobres, en esta murieron "los señores y prinçipales". ${ }^{111}$ La tercera plaga fue el hambre; la cuarta los calpizques. La quinta "los tributos grandes y serviçios que los indios hazían"; la sexta se produjo con las minas de oro. La séptima plaga fue "la edificaçión de la gran çuidad de Mexico"; la octava plaga "los esclauos que se hizieron para echar en las

${ }^{107}$ Las plagas de Egipto se narran en el Éxodo y son las siguientes: 1) "El agua se convierte en sangre" (Ex 7 14-25); 2) "Las ranas" (Ex 8 1-11); 3) "Mosquitos" (Ex 8 12-15); 4) "Los tábanos" (Ex 8 16-28); 5) "Muerte del ganado" (Ex 9 1-7); 6) "Úlceras" (Ex 9 8-12); 7) “La granizada" (Ex 9 13-35); 8) “Langostas" (Ex 10 1-20); 9) “Las tinieblas" (Ex 10 21-29);

10) "Muerte de los primogénitos" (Ex 11 1-10 y 29-34).

${ }^{108}$ Fray Toribio de Benavente Motolinía, Memoriales, estudio crítico de Nancy Joe Dyer (México: El Colegio de México, 1996), 137.

${ }^{109}$ Benavente Motolinía, Memoriales, 146.

110 Benavente Motolinía, Memoriales, 138.

111 Benavente Motolinía, Memoriales, 140. 
minas"; la novena plaga "el serviçio de las minas", con la cual "muchos pueblos se despoblaron". Y la décima plaga "las disensiones y bandos entre los españoles que estauan en México”. ${ }^{112}$

Esta tierra era una nueva Israel que tenía que huir de la idolatría, y además de las plagas había que entablar una batalla escatológica contra el demonio y vencerlo, pues "era esta tierra un traslado del infierno", ${ }^{113}$ y porque "los sacrificios y crueldades de esta tierra y gente sobrepujaron y excedieron a todas del mundo". ${ }^{114}$ Y esta batalla era la predicación de la religión verdadera para erradicar las idolatrías, sacrificios, vicios, etcétera, y también la eliminación de sus templos. ${ }^{115} \mathrm{El}$ imperio del demonio terminaría derrumbado porque Dios así lo tenía previsto; incluso, en este sentido, Motolinía y otros cronistas destacan que Moctezuma tenía conocimiento de la destrucción de su reino por las señales que aparecieron antes de su llegada:

La espiriençia nos enseña y la Escritura Sagrada lo aprueua que quando alguna gran tribulación a de venir, o Dios quiere demostrar alguna cosa notable, primero muestra Dios algunas señales en el cielo o en la tierra, demostratiuas de la tribulación venidera [...]. Y daquí es que comúndmente, antes de las mortandades y pestilençias suelen aparesçer cometas, e antes de las grandes hambres anteçeden terremotos o tempestades, e antes de las destruyçiones de los rreynos y prouinçias, aparesçen terribles visiones. Y ansí leemos que en tiempo de Antiocho, antes de la destruyción de Jerusalém y del templo, por espaçio de quarenta días fueron vistos por el ayre cauallos que discurrían y gentes armadas con lanças, y rreales y esquadrones de gentes, e otras muchas cossas, como en el dicho capítulo paresçe [...]. Bien ansi aconteçió que antes de la destruyción de México de la conquista desta Nueua España antes que los cristianos entrasen en esta tierra fueron vistas en el ayre gentes que parescían pelear vnas con otras y desta señal, nunca vista en esta tierra los indios quedaron muy marauillados. ${ }^{116}$

Esta referencia no hace más que encuadrar la acción española desde el sistema apocalíptico cristiano, y no del indígena, pues una vez pasadas las señales y la destrucción correspondiente habría una época de felicidad, era el fin de una época y el principio de otra como lo indica el mismo Motolinía.

\footnotetext{
112 Benavente Motolinía, Memoriales, 144.

113 Benavente Motolinía, Historia, trat. I, cap. 2, 24.

114 Benavente Motolinía, Memoriales, cap. 4, 36.

115 Benavente Motolinía, Memoriales, cap. 3, 29. En el libro I de su Historia de los indios describe a detalle las "idolatrías" de los indios.

${ }^{116}$ Benavente Motolinía, Memoriales, 311.
} 
Los prodigios o señales están ligados a la apocalíptica; son los signos de los tiempos, mismos que debían de ser interpretados, por lo que estos prodigios anunciaban el fin del imperio azteca ${ }^{117}$ y el establecimiento del reino cristiano. Y es en este sentido que Motolinía dice: "Destruido y acabado el rreyno tirano del demonio, començaré a dezir el rreyno de Jesucristo en el santíssimo sacramento". ${ }^{118}$ Y los franciscanos tendrían la misión de llevar a cabo la fundación de la iglesia primitiva, y es por este sentimiento de elección y de protagonismo tan caro a la orden que lo he identificado con esos hombres espirituales que establecerían esa felicidad en estas tierras, y esto se refuerza con lo que dice Ap 7 1-3, que tuvo tanta relevancia en la orden; recordemos que Francisco fue saludado como el ángel del sexto sello del Dios vivo, y al verlo de esta manera, los franciscanos debían poner el sello, y así lo cree Motolinía. ${ }^{119}$ Había entonces que marcar a los indios con el sello cristiano; por ejemplo, con el bautismo, el matrimonio, la confesión, etcétera, incluso Motolinía defendió a sus hermanos de las críticas, como las de Las Casas, por la manera de administrar el bautismo. ${ }^{120} \mathrm{Y}$ aunado a esto, se establece la importancia del número doce para la misión a estas tierras, lo que a mi parecer es una concordancia joaquinita relacionada con la época del abad, así que, dice Motolinía,

Enbió, pues, Cristo a sus doze a predicar por todo el mundo, y en toda parte y lugar fue oyda y salió la palabra de ellos, a cuyo enxemplo Sant Francisco fue e enbió sus frayles a predicar al mundo, cuya notiçia fue publicada o divulgada en todo el mundo, de que hasta nuestros tiempos ouo notiçia, ansí de fieles como de infieles. Agora que nuestro Dios descubrió aqueste otro mundo, a nosotros nueuo, porque ab eterno tenía en su mente electo al apostólico Francisco a nuestro padre el general, que es ansimismo vicario suyo, enbiasen los sobredichos rreligiosos, cuyo sonido y voz en toda la rredondez dde aqueste Nueuo Mundo a salido y a sonado hasta los fines de él o la mayor parte. ${ }^{121}$

Posteriormente el discurso sobre los indios “idólatras" cambia en fray Toribio; ahora son cristianísimos, y uno de los aspectos que resaltó fue su

117 Guy Rozat, Indios imaginarios e indios reales en los relatos de la Conquista de México (México: TAVA, 1993), 14.

118 Benavente Motolinía, Memoriales, 231.

119 Benavente Motolinía, Historia de los indios, trat. III, cap. 3, 188.

120 Benavente Motolinía, “Carta al emperador”, en Historia de los indios, 299-300.

${ }^{121}$ Benavente Motolinía, Memoriales, 134. 
pobreza, ${ }^{122}$ pero creo que la confusión está en que fue interpretada desde la visión occidental que probablemente nada tenía que ver con la noción indígena. En este sentido cabe mencionar que cuando los "doce" pasaron por Tlaxcala, durante su trayecto a México, fray Toribio escuchó a los indios decir "motolinea", y al saber que este vocablo náhuatl significaba "pobre" lo adoptó como su nombre; sin embargo, los indios lo pronunciaron por el aspecto tan diferente que tenían estos frailes en comparación con los otros españoles. ${ }^{123}$ Habría que ver qué significa la pobreza para los indios, aunque lo más seguro es que la interpretación de la pobreza realizada por fray Toribio era la de su concepción occidental.

Ahora bien, en su Historia nos da ejemplos de esa época de felicidad, nos habla de la aceptación cristiana; refiere las fiestas de Navidad, de los Reyes, de la Candelaria, el Domingo de Ramos, el Jueves Santo, así como la de san Juan, ${ }^{124}$ del corpus Christi, ${ }^{125}$ etcétera, como si fuera un paraíso terrenal, con un sabor escatológico importante. Asimismo, narra la representación de la caída de Adán y Eva que se llevó a cabo en Tlaxcala, y le sirve para mostrar su paraíso actual, perdido y reencontrado ahora, en donde hay armonía. ${ }^{126}$ En estas celebraciones hay flores de suaves olores, alegría, cantos, bailes, etcétera, que creo que refuerza esa idea paradisiaca, unida a la tercera época joaquinita. ${ }^{127}$

También cabe señalar que Motolinía, al igual que otros de sus hermanos, integró a su cuadro apocalíptico a Francisco y a Valencia, pues cumplían una función. Según Motolinía, Francisco supo de estas tierras y de la misión evangelizadora cuando fue estigmatizado en el monte Alverna. ${ }^{128}$ Y Valencia, asimismo, había sido elegido por Dios para esta misión, y lo supo por la visión de la conversión de los gentiles, ${ }^{129}$ lo que a mi parecer apoya las tesis joaquinitas de esos hombres espirituales.

Otro aspecto sobresaliente del pensamiento de Motolinía es el del mesianismo, tema que tuvo gran impacto en la península ibérica, y si bien el

122 Por ejemplo, véase Benavente Motolinía, Historia de los indios, trat. I, cap. 13, 78.

${ }^{123}$ Mendieta, Historia eclesiástica, libro III, cap. 12.

124 Benavente Motolinía, Historia de los indios, trat. I, cap. 13.

125 Benavente Motolinía, Historia de los indios, cap. 15, 85-87.

${ }^{126}$ Benavente Motolinía, Historia de los indios, cap. 15, 91-93.

127 Por ejemplo, Benavente Motolinía, Historia de los indios, cap. 13, 75. Véase también la descripción que hace de la Ciudad de los Ángeles como una nueva Jerusalén, y un paraíso. Benavente Motolinía, Memoriales, 363, 369-373.

${ }_{128}$ Benavente Motolinía, Historia de los indios, trat. III, cap. 1, 167.

129 Benavente Motolinía, Historia de los indios, trat. III, cap. 2. 
judaísmo hizo su contribución con la noción del mesías davídico y del pueblo elegido, ${ }^{130}$ hay que resaltar el influjo de la profecía del emperador de los últimos días, de la herencia de los Hohenstaufen y de los franciscanos. ${ }^{131} \mathrm{La}$ influencia de los franciscanos espirituales fue sustancial porque a partir del mismo siglo XIII reinterpretaron y popularizaron temas como el mesianismo, el anticristo, el milenio, el papa angelical, las tesis joaquinitas, etcétera. La importancia del mesianismo se observó con los Reyes Católicos, pero Carlos V, por su doble herencia, la hispánica y la imperial, fue visto como un Carolus redivivus, un nuevo Moisés o un nuevo David, incluso, con el profetismo joaquinita. ${ }^{132} \mathrm{Y}$ por su gran herencia territorial se concibió un imperio universal. Había esperanza y expectativa, quizá ligada a la propaganda política porque como último emperador se esperaba que recuperara Jerusalén, acabara con los musulmanes y el protestantismo, y la cristiandad estuviera unida bajo su reinado mesiánico.

Esta idea mesiánica fue retomada por Motolinía. En él hay un mesianismo real, pero también uno papal, y esto se observa cuando narra una representación realizada en Tlaxcala sobre la conquista de Jerusalén, ${ }^{133}$ en donde se aprecia el tema de la supremacía del mundo. Esta narración se encuadra en un esquema escatológico, y quizá sea el último ejemplo de ambas profecías; son las dos espadas, la espiritual y la material. Y así, tanto Carlos V como el papa eran los nuevos líderes de la cristiandad, habiendo una reasignación de la monarquía universal encargada de llevar el evangelio a todas partes. Aunque Motolinía remarca más la posición mesiánica del emperador, lo que se ve reflejado en la Carta que le envió en 1555, donde se observa una preocupación escatológica importante. ${ }^{134}$ Pero también liga la acción mesiánica del emperador con la de los hermanos de su orden cuando relata el sueño de los imperios históricos que Daniel le interpretó a Nabucodonosor:

${ }^{130}$ Véase el estudio de Jacques Lafaye, Mesías, cruzadas, utopías. El judeo-cristianismo en las sociedades iberoamericanas, 2a. ed. (México: Fondo de Cultura Económica, 1997).

131 Alain Milhou, "Propaganda mesiánica y opinión pública. Las reacciones de las ciudades del reino de Castilla frente al proyecto fernandino de cruzada (1510-1511)", en Pouvoir royal et absolutisme dans l'Espagne du xvie siècle (Toulouse: Université de Toulouse-Le Mirail, 1999), 33.

132 Delumeau, Historia del paraíso. Mil, 131-133.

133 Véase Benavente Motolinía, Historia de los indios, trat. I, cap. 15.

134 “Carta de Motolinía a Carlos V”, en Benavente Motolinía, Historia de los indios, 302. 
Si miramos cómo vino el señorío e imperio Romano, hallamos que primero los babilónicos en tiempo de Nabucodonosor Magno tomaron por guerra el señorío de los asirios, que, según san Gerónimo duró aquel reino más de mil e trescientos años. Y este reino de Nabucodonosor fue la cabecera de oro de la estatua que él mismo vio, según la interpretación de Daniel, cap. 2o., y Nabucodonosor fue el primero monarca y cabeza de imperio. Después, los persas y medos destruyeron a los babilónicos en tiempo de Ciro y Darío, y este señorío fueron los pechos y brazos de la misma estatua. Fueron dos brazos, conviene a saber, Ciro y Darío, y persas y medos. Después, los griegos destruyeron a los persas en tiempo de Alejandro Magno, y este señorío fue el vientre y muslos de metal, y fue de tanto sonido este metal, que se oyó por todo el mundo, salvo en esta tierra, y salió la fama y temor del grande Alejandro, que está escripto siluit terra in conspectu ejus. Y como conquistase a Asia, los de Europa y África le enviaron embajadores y le fueron a esperar con dones a Babilonia, y allí le dieron la obidiencia. Después, los romanos subjetaron a los griegos, y éstos fueron las piernas y pies de yerro, que todos los metales consume y gasta. Después, la piedra cortada del monte sin manos, cortó y disminuyó la estatua e idolatría, y éste fue el reino de Xpo [...]. Mas es de notar lo que el profeta Daniel dice en el mismo capítulo: que Dios muda los tiempos y edades, y pasa los reinos de un señorío en otro; y esto, por los pecados, según paresce en el reino de los cananeos, que lo pasó Dios en los hijos de Israel con grandísimos castigos; y el reino de Judea, por el pecado y muerte del Hijo de Dios, lo pasó a los romanos; y los imperios aquí dichos. Lo que yo a V. M. suplico es el quinto reino de Jesucristo, significado en la piedra cortada del monte sin manos, que ha de henchir y ocupar toda la tierra, del cual reino V. M. es el caudillo y capitán, que mande V. M. poner toda la diligencia que sea posible para que este reino se cumpla y ensanche y se predique a estos infieles o a los más cercanos... ${ }^{135}$

Motolinía observa que los imperios se mudan, y pide a Carlos V cumplir su papel mesiánico con ese quinto reino anunciado por Daniel. Lo anterior se puede relacionar con la profecía del emperador de los últimos días y la época joaquinita, es decir, una época escatológica vivida en la tierra. En sus Memoriales vuelve a referirse a la profecía de Daniel, pero ahora Motolinía lo hace en el cómputo del tiempo y refiriendo el sueño de Francisco:

Sé que es, segúnd una opinión, que a cinco mill y duzentos años, vno menos, que començó y hera hecho el mundo quando Cristo vino a encarnar, y más, et mill y quinientos y quarenta y dos que ay desde su aduenimiento hasta oy. Y los cathólicos

135 "Carta de Motolinía a Carlos V”, en Benavente Motolinía, Historia de los indios, 303 y 304 . 
varones y santos diuiden este tiempo en seys hedades, dexada la diuisión poética que es en quatro hedades. La primera llaman edad de oro, la segunda de plata, y la terçera de metal y la quarta de hierro. Que esto es auido otro rrespeto conforme a la estatua que vidó Sant Francisco que thenía la cabeça de oro, los pechos de plata, el cuerpo de metal y los pies de hierro. ${ }^{136}$

Ese sueño, como se vio, atravesó la historia franciscana, ya que fue Celano quien habló por vez primera de él, luego Clareno y Pisa. ${ }^{137}$ Este sueño tuvo diversas interpretaciones y una de ellas fue la que recaía en los franciscanos. Y Motolinía entronca las tradiciones del Apocalipsis de san Juan, la de Daniel y la de Joaquín de Fiore, porque no sólo el emperador sería protagonista, también ellos como orden.

Motolinía refiere que está en la sexta edad y no dice cuándo será el fin, pues su preocupación se orienta a la felicidad con los indios, como se puede ver por su preocupación escatológica, pero una vez pasado esto sí podría venir el fin, pues "como floreçió en el prinçipio la yglesia en oriente que es prinçipio del mundo, bien ansí agora en el fin de los siglos a de floreçer en oçidente, que es fin del mundo". ${ }^{138}$

\section{Conclusión}

En el franciscanismo hay una pervivencia de los temas apocalípticos desde el mismo siglo XIII hasta por lo menos la primera mitad del siglo XVI. Los franciscanos retomaron, reinterpretaron e innovaron el discurso escatológico y lo adaptaron a cada época franciscana. Y por lo hasta ahora visto, no encuentro argumentos sólidos para referir que en esos frailes que llegaron a América había un deseo del reino milenario del Apocalipsis de san Juan, pero lo que sí veo es una época escatológica ligada a la tradición joaquinita, la que desearon vivir con los indios, y esto se refuerza con su sentido de elección, de esos hombres espirituales. En la medida de lo posible he tratado de mostrar la importancia que tuvieron los temas apocalípticos en la historia franciscana, sobre todo esa idea de felicidad que se creó a partir del relato del Génesis. Hay una expectativa escatológica desde una perspectiva

136 Benavente, Motolinía, Memoriales, 547.

${ }^{137}$ Frost, "El milenarismo franciscano", 265. La doctora incluye el sueño de Bartolomé de Pisa en su trabajo.

138 Benavente Motolinía, Memoriales, 319. 
joaquinita, sin olvidar las otras tradiciones apocalípticas, pues las corrientes por lo regular aparecen fusionadas. Y esta época de felicidad también nos recuerda ese paraíso perdido que por fin podría ser recuperado. Es por eso que se observan las influencias del Apocalipsis de san Juan, de Daniel, de Joaquín de Fiore, del mesianismo imperial y papal, mismas que han estado presentes a lo largo de la historia franciscana, como ya se vio, al menos hasta la mitad del siglo XVI.

A pesar de las expectativas de Motolinía y sus hermanos, la realidad americana se impuso, ya que si bien los primeros años de la evangelización pudieron ejercer el control espiritual y temporal, y de tener protección virreinal, esa edad dorada que Motolinía quiso y describió, y que después añorara Mendieta, se fue perdiendo, se habían equivocado en sus anhelos. Su sueño se empezó a desquebrajar hacia la segunda mitad del siglo xvi, y no sólo porque las nuevas disposiciones de la Corona les restaban poder, sino porque los franciscanos se equivocaron, sólo vieron lo que su horizonte de expectativas les permitía, y su época se terminó por desvanecer.

\section{Bibliografía}

Agustín, san, La ciudad de Dios. México: Porrúa, 2008.

Alonso del Val, José María. "El milenarismo en la primera evangelización de los franciscanos en América." En Milenarismos y milenaristas en la Europa Medieval: IX Semana de Estudios Medievales. Coord. de José Ignacio de la Iglesia Duarte, 365-382. Nájera, La Rioja, España: Instituto de Estudios Regionales, 1999.

Arcelus Ulibarrena, Juana María. "Alonso de Mella en clave de lenguaje ortodoxo, tribulaciones vs. perfecta alegría." Clío \& Crimen. Revista del Centro de Historia del Crimen de Durango, n. 8 (2011): 456-480.

Baudot, Georges. Utopía e historia en México: los primeros cronistas de la civilización mexicana (1520-1569). Madrid: Espasa-Calpe, 1983.

Bayona Aznar, Bernardo. "Las lealtades de Francesc Eiximenis (1328?-1409) en el cisma y su doctrina de poder." En Doctrinas y relaciones de poder en el Cisma de Occidente y en la época conciliar (1378-1449). Ed. de José Antonio de C. R. de Sousa y Bernardo Bayona Aznar, 103-145. Zaragoza: Prensas de la Universidad de Zaragoza, 2013.

Bazán Díaz, Iñaki. "Formas de disidencia frente a la Iglesia medieval: los herejes de Durango." Norba. Revista de Historia, v. 20 (2007): 31-51. 
Bazán Díaz, Iñaki. "Los herejes de Durango: un interrogante historiográfico por responder." Clío \& Crimen. Revista del Centro de Historia del Crimen de Durango, n. 1 (2004): 261-299.

Beato de Liébana. Obras completas y complementarias. Edición bilingüe de Joaquín González Echegaray, Alberto del Campo y Leslie G. Freeman, 2 v. Madrid: Biblioteca de Autores Cristianos, Maior no. 76, 2004.

Benavente, Toribio. Historia de los indios de la Nueva España. Relación de los ritos antiguos idolatrías y sacrificios de los indios de la Nueva España, y de la maravillosa conversión que Dios en ellos ha obrado, "Sepan cuantos...", n. 129. Estudio crítico de Edmundo O’Gorman, 8a. ed. México: Porrúa, 2007.

Benavente, Toribio. Historia de los indios de la Nueva España. Edición, estudio y notas de Mercedes Serna Arnaiz y Bernat Castany Prado, Madrid: Real Academia Española; Madrid: Centro para la Edición de los Clásicos Españoles, 2014.

Benavente, Toribio. Memoriales. Estudio crítico de Nancy Joe Dyer. México: El Colegio de México, 1996.

Biblia de Jerusalén, "Sepan cuantos...” n. 500. México: Porrúa, 1998.

Buenaventura, santo. "Leyenda mayor”. En San Francisco de Asís. Escritos, biografías, documentos de la época. 2a. ed. Madrid: Biblioteca de Autores Cristianos, n. 399, 2006.

Carrasco Manchado, Ana Isabel. "Discurso político y propaganda en la corte de los Reyes Católicos (1474-1482).” Tesis doctoral, director doctor José Manuel Nieto Soria, Universidad Complutense de Madrid, Departamento de Historia Medieval, 2003.

Casale, Ubertino da. "The Tree of the Crucified Life of Jesus." En Visions of the End. Apocalyptic Traditions in the Middle Ages, de Bernard McGinn. New York: Columbia University Press, 1979.

Celano, Tomás de. "Vida primera." En San Francisco de Asís. Escritos, biografías, documentos de la época, 2a. ed. Madrid: Biblioteca de Autores Cristianos n. 399, 2006.

Celano, Tomás de. "Vida segunda." En San Francisco de Asís. Escritos, biografías, documentos de la época.

Celano, Tomás de. "Tratado de los milagros.” En San Francisco de Asís. Escritos, biografías, documentos de la época.

Clareno, Angelo. A Chronicle or History of the Seven Tribulations of the Order of Brother Minor. Trad. del latín de David Burr y E. Randolph Daniel. New York: Franciscan Institute Publications, The Franciscan Institute St. Bonaventure, 2005.

Cohn, Norman. En pos del milenio. Trad. de Ramón Alaix Busquets, apéndice y notas de Cecilia Bustamante y Julio Ortega. Madrid: Alianza, 1981. 
Colón, Cristóbal. "Libro de las profecías." En Relaciones y cartas de Cristóbal Colón, Biblioteca Clásica, tomo ClXIv. Madrid: Librería de la viuda de Hernando, 1892.

Delumeau, Jean. Historia del paraíso 1. El jardín de las delicias. México: Taurus, 2003.

Delumeau, Jean. Historia del paraíso 2. Mil años de felicidad. México: Taurus, 2003.

Delumeau, Jean. Historia del paraíso 3. ¿Qué queda del paraíso? México: Taurus, 2003.

Díaz del Castillo, Bernal. Historia verdadera de la conquista de la Nueva España, "Sepan cuantos...", n. 5. 27a. ed. México: Porrúa, 2017.

Eiximenis, Francesc. Gobierno de la República. Ed. de Miquel Castellano i Arolas. Valencia: Acció Bibliogràfica Valenciana, 2001.

"Florecillas de san Francisco y de sus compañeros." En San Francisco de Asís. Escritos, biografías, documentos de la época. 2a. ed. Madrid: Biblioteca de Autores Cristianos, núm. 399, 2006.

Frost, Elsa C. "El milenarismo franciscano en México y el profeta Daniel." Historia Mexicana, v. 26, n. 1 (1976): 3-28.

Frost, Elsa C. "¿Milenarismo mitigado imaginario?” Memorias del Simposio de Historiografía Mexicanista. México: Universidad Nacional Autónoma de México, Instituto de Investigaciones Históricas, 1990.

García Oro, José. Cisneros y la reforma del clero español en tiempos de los Reyes Católicos. Biblioteca Reyes Católicos, Estudios, 13. Madrid: Consejo Superior de Investigaciones Científicas, Instituto Jerónimo Zurita de Historia, 1971.

García Oro, José. Cisneros: un cardenal reformista en el trono de España (1436-1517). Madrid: La Esfera de los Libros, 2005.

García Oro, José. Francisco de Asís en la España medieval. Burgos: Aldecoa, 1988.

García Fernández, Ernesto. "Expresiones heréticas en la España medieval. Los herejes de Durango." En Cristianismo marginado: rebeldes, excluidos, perseguidos II. Del año 1000 al año 1500. Actas del XII Seminario sobre Historia del Monacato en Aguilar de Campo (Palencia), del 3 al 6 de agosto de 1998. Madrid: Fundación Santa María la Real, Centro de Estudios del Románico; Madrid: Ediciones Polifemo, 1999.

Gil Fernández, Juan. "El nudo gordiano y Fernando el Católico." Habis, n. 16 (Universidad de Sevilla, 1985): 229-242.

Gómez Canedo, Lino. Evangelización, cultura y promoción social. Ensayos y estudios críticos sobre la contribución franciscana a los orígenes cristianos de México (siglos XVI-XVIII). Biblioteca Porrúa, n. 109. México: Porrúa, 1993.

Jedin, Hubert. Breve historia de los concilios, 3a. ed. Barcelona: Herder, 1963. 
Jiménez, Francisco, fray. "Vida de fray Martín de Valencia." Ed. preparada por Pedro Ángeles Jiménez. En La hermana pobreza. El franciscanismo: de la Edad Media a la evangelización novohispana, de Antonio Rubial. México: Universidad Nacional Autónoma de México, Facultad de Filosofía y Letras, 2006.

Lafaye, Jacques. Mesías, cruzadas, utopías. El judeo-cristianismo en las sociedades iberoamericanas. 2a. ed. México: Fondo de Cultura Económica, 1997.

Le Goff, Jacques. San Francisco de Asís. Trad. de Eduardo Canero Santamaría. Madrid: Akal, 2003.

Ladero Quesada, Miguel Ángel. La España de los Reyes Católicos. 4a. ed. Madrid: Alianza Editorial, 2014.

McGinn, Bernard. Visions of the End. Apocalyptic Traditions in the Middle Ages. New York: Columbia University Press, 1979.

Mendieta, Gerónimo. Historia eclesiástica indiana. Est. introd. de Antonio Rubial García. Cien de México. México: Consejo Nacional para las Cultura y las Artes, 2002.

Milhou, Alain. Colón y su mentalidad mesiánica en el ambiente franciscanista español. Cuadernos Colombinos, 11. Sevilla: Casa-Museo de Colón; Valladolid: Universidad de Valladolid, Seminario Americanista, 1983.

Milhou, Alain. "Propaganda mesiánica y opinión pública. Las reacciones de las ciudades del reino de Castilla frente al proyecto fernandino de cruzada (15101511)." En Pouvoir royal et absolutisme dans l'Espagne du xvie siècle. Toulouse: Université de Tolouse-Le Mirail, 1999.

Muro Abad, Robert. “Durango, 1442. Sueño efímero de salvación.” En Milenarismos y milenaristas en la Europa medieval: IX Semana de Estudios Medievales, 349-363. Nájera, España: Instituto de Estudios Regionales, 1999.

Nieto Soria, José Manuel. "Apología y propaganda de la realeza en los cancioneros castellanos del siglo xv. Diseño literario de un modelo político." En la España Medieval, n. 11 (Madrid, 1988): 185-221.

Ockham, Guillermo de. Sobre el gobierno tiránico del papa. 2a. ed. Madrid: Tecnos, 2008.

Olivi, Peter. "Commentary on Revelation." En Visions of the End. Apocalyptic Traditions in the Middle Ages, de Bernard McGinn. New York: Columbia University Press, 1979.

Parma, Juan de. "Sacrum Commercium." En San Francisco de Asís. Escritos, biografías, documentos de la época. 2a. ed., Madrid: Biblioteca de Autores Cristianos n. 399, 2006.

Peña Eguren, Esteban. La filosofía política de Guillermo de Ockham. Relación entre potestad civil y potestad eclesiástica. Estudio sobre el "Dialogus, pars III." Madrid: Encuentro, 2005. 
Phelan, John L. El reino milenario de los franciscanos en el Nuevo Mundo. México: Universidad Nacional Autónoma de México, Instituto de Investigaciones Históricas, 1972 (1a. ed. en inglés 1956).

Ratzinger, Joseph. La teología de la historia de san Buenaventura. Madrid: Encuentro, 2004.

Reguera, Iñaki. “La Inquisición en el País Vasco. El periodo fundacional.” Clío \& Crimen, Revista del Centro de Historia del Crimen de Durango, n. 2 (2005): 237-255.

Rozat Dupeyron, Guy. Indios imaginarios e indios reales en los relatos de la Conquista de México. México: tava, 1993.

Rubial, Antonio. La hermana pobreza. El franciscanismo: de la Edad Media a la evangelización novohispana. México: Universidad Nacional Autónoma de México, Facultad de Filosofía y Letras, 2006.

Saranyana, José Ignacio. Joaquín de Fiore y Tomás de Aquino. Historia doctrinal de una polémica. Colección Teológica, n. 22. Pamplona: Ediciones de la Universidad de Navarra, 1979.

Toro Pascua, María Isabel. "Milenarismo y profecía en el siglo xv: la tradición del libro de Unay en la península ibérica." Península, Revista de Estudios Ibéricos, n. 0 (2003): 29-37.

Varela Marcos, Jesús. Colón: su tesis "pezonoidal" del globo terráqueo y el itinerario del tercer viaje: la fantasía del paraíso terrenal. Valladolid: Universidad de Valladolid, Instituto Interuniversitario de Estudios de Iberoamérica y Portugal, 2002.

West, Delno C., y Sandra Zimdars-Swartz. Joaquín de Fiore. Una visión espiritual de la historia. Cuadernos de la Gaceta, n. 22. México: Fondo de Cultura Económica, 1986. 